\title{
Appraising the Spectral Interference of Dysprosium on 27 Analytes Using Capacitively Coupled Device Detector- based Inductively Coupled Plasma Atomic Emission Spectrometry Without Physical/Chemical Separation
}

\author{
Arijit Sengupta $^{a^{*}}$, Yougant Airan ${ }^{b}$, S.K. Thulasidas ${ }^{a}$, and V. Natarajan ${ }^{a}$ \\ a Radiochemistry Division, Bhabha Atomic Research Centre, Trombay, Mumbai, India \\ b Chemistry Department, Hindu College, University of Delhi, Delhi, India
}

\section{INTRODUCTION}

The qualities and functions of lanthanides have long been the focus of research. Since lanthanides possess similar chemical and physical properties, they are difficult to separate. Due to their various uses in industry, they find application in many important and fundamental areas such as the functional materials in agriculture, as catalysts, and for other products. They easily enter into the environment and accumulate in organisms and finally become part of the food chain (1-4). The distinctive nature of unpaired $4 \mathrm{f}$ electrons causes the rare earth elements (REEs) to possess particular physical and chemical properties. Among the lanthanides, dysprosium (Dy) possesses high magnetic momentum (around $10.65 \mu \mathrm{B}$ ) and is used in various fields such as magnetic and magneto-optical recording with a large magnetostriction, magnetocaloric, etc. (5-9). The oxide of Dy, $\mathrm{Dy}_{2} \mathrm{O}_{3}$, is highly insoluble and thermally stable, suitable for glass, optical, and ceramic applications. (10).

In this study, a capacitively coupled device (CCD) as the detector in inductively coupled plasma atomic emission spectrometry (ICP-AES) analysis was used which records the spectrum over a large wavelength range owing to the coupling of a solid state array detector with an Echelle spectrograph. This wide coverage has the

\footnotetext{
*Corresponding autbor.

:E-mai: arijita@barc.gov.in
}

\begin{abstract}
In this work, a capacitively coupled device-based inductively coupled plasma atomic emission spectrometry method was used to determine the spectral interference of electron-rich elements for assessing some common analytes (Ag, Al, B, Ba, Ca, Cd, Co, $\mathrm{Cr}, \mathrm{Cu}, \mathrm{Fe}, \mathrm{Ga}, \mathrm{In}, \mathrm{Li}, \mathrm{Mg}, \mathrm{Mn}, \mathrm{Na}$, $\mathrm{Ni}, \mathrm{Sr}, \mathrm{Pb}, \mathrm{Tl}$, and $\mathrm{Zn}$ ) and some rare earth elements (Ce, Gd, La, $\mathrm{Lu}, \mathrm{Nd}$, and $\mathrm{Pr}$ ) in a dysprosium matrix. The foremost lines for each of these elements were chosen after checking the analytical performance such as sensitivity, detection limit, linear dynamic range and precision, tolerance level, and correction factor due to the spectral interference of the electron-rich dysprosium (Dy). This methodology was verified by using synthetic samples and comparing the results with other reliable methods. The proposed method is efficient, simple, and less time-consuming for the determination of analytes in a Dy matrix without requiring physical/chemical separation.
\end{abstract}

special benefit of performing simultaneous multi-element detection and obtains spectral-free lines for each element as required for qualitative analysis (11). The CCD detector provides better resolution so that the spectral-free lines of the trace elements and the REEs can be determined.

The ICP-AES method provides high sensitivity, a large dynamic range, reproducibility, and exceptional stability from matrix effects for the determination of trace amounts of REEs in geological and related materials (12-17). Matrix effects are mainly due to the high concentration range of REEs beyond their instrumental detection limits which then poses a problem in the determination of REEs present in low concentrations in many common substances (18). Most of the matrix elements falsify REE analytical results because of spectral overlaps and background continuum interferences. This problem could not be resolved with previous methods routinely used before ICP-OES, such as neutron activation analysis (NAA), $\mathrm{X}$-ray fluorescence (XRF), and mass spectroscopy, etc. (19-22).

In our previous studies, the spectral interference of $\mathrm{U}, \mathrm{Th}, \mathrm{Zr}, \mathrm{Gd}$, $\mathrm{Lu}$, and $\mathrm{Nd}$ on different analytes and its implication in trace metallic impurity analysis (23-30) was investigated. In the present work, Dy was chosen as the emission-rich matrix and its spectral interference on common analytes, including specified rare earth elements.

\section{EXPERIMENTAL}

\section{Instrumental Operating Conditions}

The analysis was carried out using a Model Arcos FHS12 ICP-AES (Arcos, Germany), equipped with a high temperature argon plasma as a source of excitation and CCD as the detector system. The instrumental operating conditions and specifications are listed in Table I. The 
detector system, consisting of linear arrays of CCD detectors (3648 pixels/array) and thermally stabilized, provides the ability to select alternate analytical lines.

\section{Standard Solutions and Reagents}

Standard solutions for all of the elements were prepared from Certipur ${ }^{\circledR}$ ICP standard reference material solutions (E-Merck, Darmstadt, Germany) by proper dilution. Suprapur ${ }^{\circledR} \mathrm{HNO}_{3}$ (E-Merck, Darmstadt, Germany) and quartz doubledistilled water were used throughout the study. Even though ICP-AES offers a high degree of linear dynamic range, for more precise calibration curves multi-point standardization was carried out using $0.5 \mathrm{M} \mathrm{HNO}_{3}$ as a lower standard and $0.05-500 \mathrm{mg} / \mathrm{L}$ of the corres- ponding elemental standard as the higher standard for each line after proper peak search, auto-attenuation, etc. For the analysis of each sample, 10 replicate measurements were carried out, while for determination of the detection limits and sensitivity, 25 replicate measurements were taken into account.

\section{Methods}

The method chosen for studying the spectral interference and selecting the best line(s) in the presence of Dy, each analyte was studied by preparing a series of Dy solutions (standard reference material elemental solution from E-Merck, Darmstadt, Germany) of varying concentrations from $0.05 \mathrm{mg} / \mathrm{L}$ to $500 \mathrm{mg} / \mathrm{L}$. The contribution due to Dy in each different channel of each of the analytes was observed

TABLE I

Specifications and Instrumental Operating Conditions of ICP-AES

Instrumental Specifications

\begin{tabular}{ll} 
Optical design & Arcos FHS12 ICP-AES \\
Paschen-Runge mounting & Circular design \\
Focal length & $750 \mathrm{~mm}$ \\
Grating & Holographic \\
Groove density & 1800 grooves $/ \mathrm{mm}(1), 3600$ grooves $/ \mathrm{mm}(2)$ \\
Wavelength range & $130-800 \mathrm{~nm}$ \\
Entrance slit width & $15 \mathrm{microns}$ \\
Resolution (FWHM) & $0.01 \mathrm{~nm}$ from $130-450 \mathrm{~nm}$ \\
& $0.02 \mathrm{~nm}$ from $450-800 \mathrm{~nm}$ \\
Thermal regulation & Controlled to $30 \pm 1{ }^{\circ} \mathrm{C}$ \\
Frequency & $27.12 \mathrm{MHz}$ \\
Pump & Dual channel peristaltic pump \\
Detector & Linear arrays of CCD (3648 pixels/array) \\
Nebulizer & Cross flow \\
ICP-torch & Demountable, radial viewing \\
\hline Operating Conditions & \\
Coolant flow & $16 \mathrm{~L} / \mathrm{min}$ \\
Auxiliary flow & $0.5 \mathrm{~L} / \mathrm{min}$ \\
Total time of measurement & $26 \mathrm{~s}$ \\
Pump speed & $28 \mathrm{rpm}$ \\
RF power output & $1.1 \mathrm{~kW}$ \\
Input power & $230 \mathrm{~V}$ AC
\end{tabular}

\section{Atomic Apectroscopy \\ 1 Vol. 37(2), March/April 2016}

and the correction factor, tolerance level, as well as the analytical performance, such as detection limit, sensitivity, linear dynamic range, and precision for each analyte, were evaluated. Considering that the correction factor depends on the concentration of the interfering element (Dy), ICP-AES is the method of choice to directly determine the interferent in the presence of other analytes. The analytical performance for each identified line of Dy was evaluated. The tolerance level is the maximum concentration of the interfering element up to which point there is no spectral interference on the particular emission line of the analyte.

Background correction was performed by the two-point method off-line after the experiments were carried out. In the two-point calibration, two points have to be chosen on both sides of the peak. The software of the instrument then creates a straight line considering these two points. This straight line is considered the background for the peak corresponding to the analytical line.

The developed methodology for the direct determination of trace amounts of 27 analytes (Ag, Al, B, $\mathrm{Ba}, \mathrm{Ca}, \mathrm{Cd}, \mathrm{Co}, \mathrm{Cr}, \mathrm{Cu}, \mathrm{Fe}, \mathrm{Ga}$, In, $\mathrm{Li}, \mathrm{Mg}, \mathrm{Mn}, \mathrm{Na}, \mathrm{Ni}, \mathrm{Sr}, \mathrm{Pb}, \mathrm{Tl}$, and $\mathrm{Zn})$ and some rare earth elements (Ce, Gd, La, Lu, Nd, and Pr) was performed using synthetic samples without chemical separation. The method was compared with other techniques for determining trace amount of common analytes, except for $\mathrm{Ag}$, which is being added to the sample in the form of $\mathrm{AgCl}$. The D.C. arc carrier distillation technique was used, while for the rare earth elements ion chromatography was used for comparison purposes. The results obtained from this newly developed method were compared with flame atomic absorption spectrometry (FAAS) analysis. 


\section{RESULTS AND DISCUSSION}

\section{Simultaneous Determination of Dy by ICP-AES}

Since the contribution of Dy on different analytes is dependent on its concentration, it is required that the correct amount present in the sample is determined. Also, for defining the spectral interference quantitatively, the correction factor (which is a function of the concentration of the interfering element) of each identified line must be known. An ICP-AES method was developed for the determination of Dy along with the analytes. Even though Dy has a line-rich emission spectra, only five lines were chosen on the basis of the analytical performance. The calibration curves for the five chosen lines of Dy (340.780 nm, $353.170 \mathrm{~nm}, 353.602$ $\mathrm{nm}, 364.540 \mathrm{~nm}$, and $394.468 \mathrm{~nm}$ ) were established as shown in Figure 1 . The detection limit of Dy using these lines follows the trend: $353.170 \mathrm{~nm}<364.540 \mathrm{~nm}<$ $340.780 \mathrm{~nm}<394.468 \mathrm{~nm}<$ $353.602 \mathrm{~nm}$, while that of sensitivity follows the trend: $353.170 \mathrm{~nm}$ $>364.540 \mathrm{~nm}>340.780 \mathrm{~nm} \sim$ $353.602 \mathrm{~nm}>394.468 \mathrm{~nm}$, respectively. The slope of the calibration curves was considered as the sensitivity of the analytical lines, whereas the detection limits were calculated as the concentration equivalent to the intensity of the blank $(<x\rangle)+5$ times of the rela- tive standard deviation values of the blank $(5 \sigma)$. Synthetic samples containing Dy in the concentration range of $0.05 \mathrm{mg} / \mathrm{L}-500 \mathrm{mg} / \mathrm{L}$ were analyzed using these analytical lines to validate the method for the determination of Dy. The analytical results are summarized in Table II.

\section{Spectral Interference of Dy on Other Analytes}

Dysprosium is an important member of the lanthanide series and has [Xe] $4 \mathrm{f}^{10}, 6 \mathrm{~s}^{2}$ ground state electronic configuration and ${ }^{5} \mathrm{I}_{8}$ ground state term. The spectral study of Dy revealed various transition lines in the spectrum due to its multi-electronic nature and, there- fore, it interfered in the determination of other analytes. The study of spectral interference along with the analytical performance for each analyte is shown in Tables III-VIII. The best lines for each analyte were chosen on the basis of spectral interference and analytical performance (detection limit, sensitivity, linear synamic range, and precision).

Effect on Cd, Li, Mn, Sr, Pr, Na, $\mathrm{Zn}, \mathrm{La}, \mathrm{Lu}$, and $\mathrm{Mg}$

These analytes are selectively grouped because they have some spectral-free line(s) as shown in Table III, and their analytical performance is listed in Table IV.

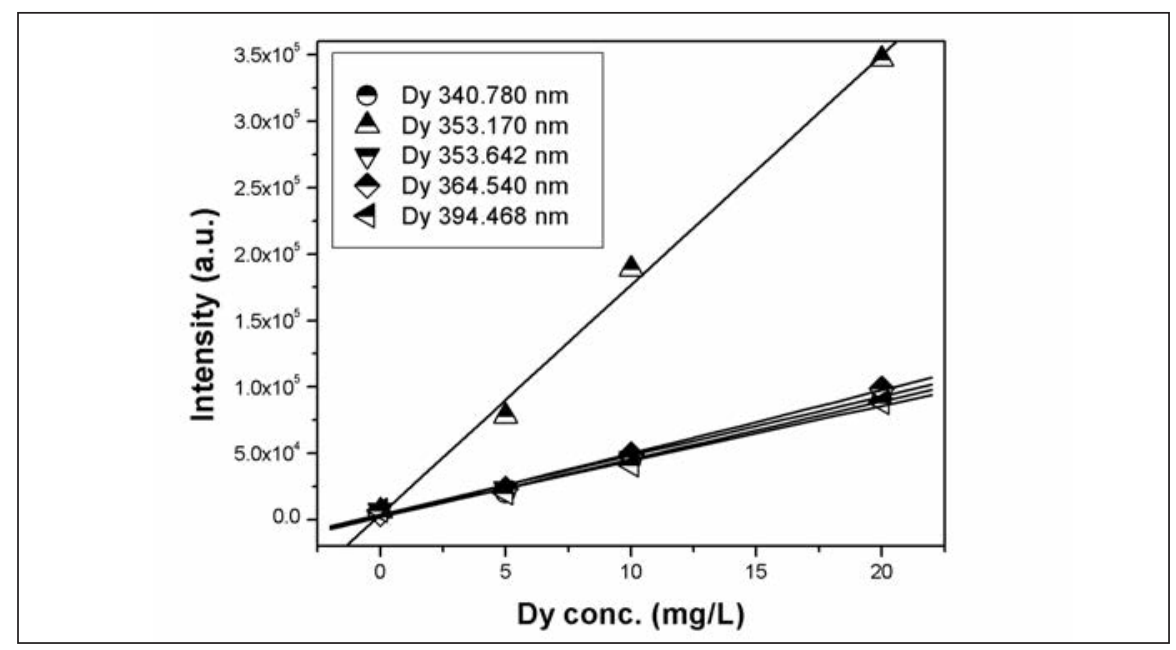

Fig: 1. Calibration Curves for Different Analytical Lines of Dy.

TABLE II

Determination of Dy by ICP-AES

\begin{tabular}{|c|c|c|c|c|c|}
\hline Dy $(\mathrm{mg} / \mathrm{L})$ & $\begin{array}{c}340.78 \mathrm{~nm} \\
(\mathrm{mg} / \mathrm{L})\end{array}$ & $\begin{array}{c}353.17 \mathrm{~nm} \\
(\mathrm{mg} / \mathrm{L})\end{array}$ & $\begin{array}{l}353.602 \mathrm{~nm} \\
(\mathrm{mg} / \mathrm{L})\end{array}$ & $\begin{array}{c}364.54 \mathrm{~nm} \\
(\mathrm{mg} / \mathrm{L})\end{array}$ & $\begin{array}{c}394.468 \mathrm{~nm} \\
(\mathrm{mg} / \mathrm{L})\end{array}$ \\
\hline 1 & $0.97 \pm 0.04$ & $1.07 \pm 0.05$ & $1.02 \pm 0.06$ & $0.99 \pm 0.04$ & $0.98 \pm 0.04$ \\
\hline 10 & $10.4 \pm 0.5$ & $9.7 \pm 0.5$ & $9.5 \pm 0.5$ & $10.2 \pm 0.4$ & $9.6 \pm 0.4$ \\
\hline 50 & $51 \pm 2$ & $47 \pm 3$ & $49 \pm 3$ & $50 \pm 3$ & $50 \pm 5$ \\
\hline 100 & $96 \pm 5$ & $101 \pm 3$ & $104 \pm 5$ & $97 \pm 3$ & $98 \pm 4$ \\
\hline 500 & $489 \pm 10$ & $497 \pm 8$ & $508 \pm 9$ & $503 \pm 5$ & $500 \pm 6$ \\
\hline D.L. (mg/L) & 0.046 & 0.006 & 0.065 & 0.032 & 0.05 \\
\hline Sensitivity (counts/mg/L) & $4.2 \times 10^{3}$ & $17 \times 10^{3}$ & $4.4 \times 10^{3}$ & $4.7 \times 10^{3}$ & $4.1 \times 10^{3}$ \\
\hline Linear Dynamic Range (mg/L) & $0.046-1000$ & $0.006-1000$ & $0.065-1000$ & $0.032-1000$ & $0.050-1000$ \\
\hline
\end{tabular}




\section{Cadmium (Cd)}

Cadmium has one spectral-free line, $226.502 \mathrm{~nm}$, among its four chosen lines. The sensitivity for the four lines follows the order: $226.502 \mathrm{~nm}>214.438 \mathrm{~nm}>$ $228.802 \mathrm{~nm}>361.051 \mathrm{~nm}$. Thus, the Cd 226.502-nm line is chosen for further quantitative analysis.

\section{Litbium (Li)}

The only line which seems best for Li, based on both the analytical performance and spectral interference, is $670.780 \mathrm{~nm}$ and was chosen for further studies.

\section{Manganese (Mn)}

Though the analytical performance results for the five lines of $\mathrm{Mn}$ (257.611 nm, $259.373 \mathrm{~nm}, 260.569$ $\mathrm{nm}, 294.921 \mathrm{~nm}$, and $403.076 \mathrm{~nm}$ ) are found to be similar, the spectral interference result reveals that the only line of $\mathrm{Mn}$ that is not interfered is $259.373 \mathrm{~nm}$ and hence, was chosen for further studies in a Dy matrix.

\section{Strontium (Sr)}

Among the three lines of $\mathrm{Sr}$ (407.771 nm, $421.552 \mathrm{~nm}$, and $460.733 \mathrm{~nm}$ ), the former two lines show similar analytical performance (includes detection limit, sensitivity, linear dynamic range, \%RSD). However, the 421.552-nm line was found not to be interfered in a Dy matrix, while the 407.771-nm line does. Thus, the 421.552-nm line was selectively chosen for the quantitative studies of Sr in a Dy matrix.

\section{Praseodium (Pr)}

The sensitivity of all four lines of $\operatorname{Pr}(411.846 \mathrm{~nm}, 417.939 \mathrm{~nm}$, $422.535 \mathrm{~nm}$, and $414.311 \mathrm{~nm}$ ) were found to be similar. The only line that is not interfered by Dy is $417.939 \mathrm{~nm}$ and thus was chosen as the best line for use in further studies.

\section{Sodium (Na)}

The two lines $(588.995 \mathrm{~nm}$ and $589.592 \mathrm{~nm}$ ) of $\mathrm{Na}$ were found to have similar analytical performance results and are not interfered in a Dy matrix. Thus, these two lines are best for the quantitative study of $\mathrm{Na}$ in a Dy matrix.

\section{Zinc (Zn)}

The detection limit trend for the four lines of $\mathrm{Zn}$ is as follows: $213.856 \mathrm{~nm}<202.613 \mathrm{~nm}<$ $206.200 \mathrm{~nm}<334.502 \mathrm{~nm}$. It was found that the $213.856-\mathrm{nm}$ line is the only line of $\mathrm{Zn}$ which is not interfered in a Dy matrix. Thus, the 213.856-nm line of $\mathrm{Zn}$ is best for further studies in a Dy matrix.

\section{Lantbanum (La)}

All three lines of $\mathrm{La}(333.749 \mathrm{~nm}$, $379.478 \mathrm{~nm}$, and $408.672 \mathrm{~nm}$ ) show similar detection limit, but the 333.749-nm line is interfered. Thus, the 379.478-nm and 408.672$\mathrm{nm}$ lines were chosen for quantitative study of La in a Dy matrix.

\section{Lutetium (Lu)}

From both the analytical performance and spectral interference point of view, the $261.542-\mathrm{nm}$ line of Lu was found best for the estimation of Lu in a Dy matrix.

\section{Magnesium (Mg)}

The detection limit trend for the five lines of $\mathrm{Mg}$ is: $279.553 \mathrm{~nm}$ $<280.270 \mathrm{~nm}<285.213 \mathrm{~nm}<$ $202.647 \mathrm{~nm}<279.079 \mathrm{~nm}$, respectively, while the sensitivity trend is just the reverse. The only line not interfered by Dy is $279.553 \mathrm{~nm}$ and hence, was chosen the best analytical line of $\mathrm{Mg}$ in a Dy matrix.

\section{Effect on Ca, Fe, Co, Cu, Tl, Ag, $\mathrm{B}$, and $\mathrm{Cr}$}

These eight analytes are selectively grouped because there are some line(s) of each analyte which are slightly interfered in a Dy matrix (see Table V). After incorporating the correction factor, it is possible to determine these analytes in a Dy matrix. The analytical performance result of these analytes is shown in Table VI.

\section{Appectroscopy}

\section{Calcium (Ca)}

The detection limit trend of the six chosen lines of $\mathrm{Ca}$ is: 393.366 $\mathrm{nm}<396.847 \mathrm{~nm}<422.673 \mathrm{~nm}$ $<317.933 \mathrm{~nm}<315.887 \mathrm{~nm}<$ $183.801 \mathrm{~nm}$. The sensitivity follows the reverse trend of the detection limit. The 393.366-nm line was found to interfere the least and was therefore chosen for studying $\mathrm{Ca}$ in a Dy matrix.

\section{Iron $(\mathrm{Fe})$}

Among the 10 analytical lines of $\mathrm{Fe}$, the 239.562-nm line was found to interfere the least and had the best analytical performance results. Hence, this line was chosen for the quantitative determination of $\mathrm{Fe}$ in a Dy matrix.

\section{Cobalt (Co)}

The contribution of the four lines of Co in a Dy matrix follows the trend: $237.862 \mathrm{~nm}<238.892 \mathrm{~nm}$ $<228.616 \mathrm{~nm}<230.786 \mathrm{~nm}$, respectively. The $237.862-\mathrm{nm}$ line has the lowest detection limit in comparison to the other lines. Thus, it was selected as the best analytical line for Co in a Dy matrix.

\section{Copper (Cu)}

The contribution of the five lines of $\mathrm{Cu}$ in a Dy matrix follows the trend: $324.754 \mathrm{~nm}<327.396 \mathrm{~nm}$ $<224.700 \mathrm{~nm}<219.958 \mathrm{~nm}$ $<219.226 \mathrm{~nm}$, respectively. The 324.754-nm line was found to have lower detection limit and higher sensitivity in comparison to the other lines. Hence, it was selected for Cu determination in a Dy matrix.

\section{Thallium (T1)}

Among the two lines of $\mathrm{Tl}$ (190.864 $\mathrm{nm}$ and $276.787 \mathrm{~nm}$ ), the only line worth noticing is $\mathbf{1 9 0 . 8 6 4}$ $\mathrm{nm}$. This line has better analytical performance and spectral interference results than the $276.787 \mathrm{~nm}$ line and thus, was chosen best for studying $\mathrm{Tl}$ in a Dy matrix. 
TABLE III

Spectral Interference of Dy on Cd, Li, Mn, Sr, Pr, Na, Zn, La, Lu, and Mg

\begin{tabular}{|c|c|c|c|c|c|c|c|c|c|}
\hline $\begin{array}{c}\text { Ele- } \\
\text { ments }\end{array}$ & $\begin{array}{c}\text { Analytical } \\
\text { Lines } \\
(\mathrm{nm})\end{array}$ & $\begin{array}{c}\text { Contribution } \\
\text { From } 500 \\
\mathrm{mg} / \mathrm{L} \text { of Dy }\end{array}$ & $\begin{array}{c}\text { Correction } \\
\text { Factor }\end{array}$ & $\begin{array}{c}\text { Tolerance } \\
\text { Level } \\
(\mathrm{mg} / \mathrm{L})\end{array}$ & $\begin{array}{c}\text { Ele- } \\
\text { ments }\end{array}$ & $\begin{array}{c}\text { Analytical } \\
\text { Lines } \\
(\mathrm{nm})\end{array}$ & $\begin{array}{c}\text { Contribution } \\
\text { From } 500 \\
\text { mg/L of Dy }\end{array}$ & $\begin{array}{l}\text { Correction } \\
\text { Factor }\end{array}$ & $\begin{array}{c}\text { Tolerance } \\
\text { Level } \\
(\mathrm{mg} / \mathrm{L}) \\
\end{array}$ \\
\hline \multirow[t]{4}{*}{$\mathrm{Cd}$} & 214.438 & 0.07 & $1.4 \times 10^{-4}$ & 200 & \multirow[t]{4}{*}{$\mathrm{Na}$} & 589.592 & $*$ & - & 0.5 \\
\hline & 226.502 & $*$ & - & 500 & & 588.995 & $*$ & - & 0.5 \\
\hline & 228.802 & 0.71 & $1.4 \times 10^{-3}$ & 5 & & 330.237 & \# & - & 1 \\
\hline & 361.051 & 9.61 & $1.9 \times 10^{-2}$ & 10 & & 330.298 & \# & - & 5 \\
\hline \multirow[t]{4}{*}{$\mathrm{Li}$} & 670.78 & $*$ & - & 500 & \multirow[t]{4}{*}{$\mathrm{Zn}$} & 213.856 & $*$ & - & 0.5 \\
\hline & 460.289 & 1.31 & $2.6 \times 10^{-3}$ & 200 & & 206.200 & 1.90 & $3.8 \times 10^{-3}$ & 5 \\
\hline & 323.261 & \# & - & 0.05 & & 202.613 & 0.23 & $4.5 \times 10^{-4}$ & 0.5 \\
\hline & 274.118 & 8.0 & $1.6 \times 10^{-2}$ & 50 & & 334.502 & 14.0 & $2.8 \times 10^{-2}$ & 5 \\
\hline \multirow[t]{5}{*}{ Mn } & 257.611 & 0.17 & $3.4 \times 10^{-4}$ & 200 & \multirow[t]{3}{*}{$\mathrm{La}$} & 408.672 & $*$ & - & 500 \\
\hline & 259.373 & $*$ & - & 200 & & 333.749 & 2.03 & $4.1 \times 10^{-3}$ & 10 \\
\hline & 260.569 & 0.09 & $1.8 \times 10^{-4}$ & 200 & & 379.478 & $*$ & - & 500 \\
\hline & 294.921 & 1.62 & $3.2 \times 10^{-3}$ & 5 & \multirow[t]{4}{*}{$\mathrm{Lu}$} & 261.542 & $*$ & $2.0 \times 10^{-4}$ & 500 \\
\hline & 403.076 & 0.10 & $2.0 \times 10^{-4}$ & 200 & & 291.139 & 0.68 & $1.3 \times 10^{-3}$ & 50 \\
\hline \multirow[t]{3}{*}{$\mathrm{Sr}$} & 407.771 & 0.58 & $1.2 \times 10^{-3}$ & 50 & & 307.760 & 0.36 & $7.1 \times 10^{-4}$ & 200 \\
\hline & 421.552 & $*$ & - & 500 & & 219.554 & 0.36 & $7.2 \times 10^{-4}$ & 50 \\
\hline & 460.733 & 0.31 & $6.1 \times 10^{-4}$ & 50 & \multirow[t]{5}{*}{$\mathrm{Mg}$} & 279.553 & $*$ & - & 0.5 \\
\hline \multirow[t]{4}{*}{$\operatorname{Pr}$} & 411.846 & 0.48 & $9.6 \times 10^{-4}$ & 200 & & 280.270 & 0.08 & $1.5 \times 10^{-4}$ & 0.5 \\
\hline & 417.939 & $*$ & - & 500 & & 285.213 & 0.10 & $2.0 \times 10^{-4}$ & 50 \\
\hline & 422.535 & 1.37 & $2.7 \times 10^{-3}$ & 10 & & 279.079 & 3.50 & $7.0 \times 10^{-3}$ & 1 \\
\hline & 414.311 & $\#$ & - & 0.05 & & 202.647 & 0.69 & $1.4 \times 10^{-3}$ & 0.05 \\
\hline
\end{tabular}

*No interference.

\#significant spectral interference.

TABLE IV

Analytical Performance of Cd, Li, Mn, Sr, Pr, Na, Zn, La, Lu, and Mg in Dy Matrix

\begin{tabular}{|c|c|c|c|c|c|c|c|c|c|c|c|}
\hline $\begin{array}{l}\text { Ele- } \\
\text { ments }\end{array}$ & $\begin{array}{l}\text { Analytical } \\
\text { Lines } \\
(\mathrm{nm})\end{array}$ & $\begin{array}{c}\text { D.L. } \\
(\mathrm{mg} / \mathrm{L})\end{array}$ & $\begin{array}{l}\text { Sensitivity } \\
\text { (counts/ } \\
\text { mg/L) }\end{array}$ & $\begin{array}{c}\text { Linear } \\
\text { Dynamic } \\
\text { Range }(\mathrm{mg} / \mathrm{L})\end{array}$ & $\begin{array}{l}\text { RSD } \\
(\%)\end{array}$ & $\begin{array}{l}\text { Ele- } \\
\text { ments }\end{array}$ & $\begin{array}{l}\text { Analytical } \\
\text { Lines } \\
(\mathrm{nm})\end{array}$ & $\begin{array}{c}\text { D.L. } \\
(\mathrm{mg} / \mathrm{L})\end{array}$ & $\begin{array}{c}\text { Sensitivity } \\
\text { (counts/ } \\
\mathrm{mg} / \mathrm{L})\end{array}$ & $\begin{array}{c}\text { Linear } \\
\text { Dynmaic } \\
\text { Range }(\mathrm{mg} / \mathrm{L})\end{array}$ & $\begin{array}{l}\text { RSD } \\
(\%)\end{array}$ \\
\hline \multirow[t]{4}{*}{$\mathrm{Cd}$} & 214.438 & 0.007 & 4084 & $0.007-1000$ & 2 & $\mathrm{Na}$ & 330.237 & 1.97 & 61 & $1.91-800$ & 4 \\
\hline & 226.502 & 0.007 & 8972 & $0.007-1000$ & 2 & & 330.298 & 2.37 & 36 & $2.37-800$ & 4 \\
\hline & 228.802 & 0.04 & 1354 & $0.04-800$ & 5 & & 588.995 & 0.03 & 47676 & $0.03-1000$ & 1 \\
\hline & 361.051 & 0.51 & 331 & $0.51-500$ & 5 & & 589.592 & 0.01 & 27818 & $0.01-1000$ & 1 \\
\hline \multirow[t]{4}{*}{$\mathrm{Li}$} & 274.118 & 1.52 & 34 & $1.52-500$ & 5 & $\mathrm{Zn}$ & 202.613 & 0.03 & 1649 & $0.03-1000$ & 2 \\
\hline & 323.261 & 0.22 & 147 & $0.22-900$ & 4 & & 206.200 & 0.2 & 144 & $0.2-900$ & 2 \\
\hline & 460.289 & 0.53 & 176 & $0.53-1000$ & 2 & & 213.856 & 0.002 & 14112 & $0.002-1000$ & 1 \\
\hline & 670.78 & 0.002 & 175101 & $0.002-1000$ & 1 & & 334.502 & 0.44 & 379 & $0.44-850$ & 1 \\
\hline \multirow[t]{5}{*}{$\mathrm{Mn}$} & 257.611 & 0.003 & 9189 & $0.003-1000$ & 1 & $\mathrm{La}$ & 333.749 & 0.04 & 4104 & $0.04-1000$ & 1 \\
\hline & 259.373 & 0.003 & 8067 & $0.003-1000$ & 1 & & 379.478 & 0.04 & 6022 & $0.04-1000$ & 1 \\
\hline & 260.569 & 0.001 & 4193 & $0.001-1000$ & 1 & & 408.672 & 0.03 & 7071 & $0.03-1000$ & 1 \\
\hline & 294.921 & 0.05 & 1454 & $0.05-950$ & 2 & $\mathrm{Lu}$ & 219.554 & 0.02 & 986 & $0.02-900$ & 2 \\
\hline & 403.076 & 0.02 & 8572 & $0.02-975$ & 2 & & 261.542 & 0.004 & 7184 & $0.004-1000$ & 2 \\
\hline \multirow[t]{3}{*}{$\mathrm{Sr}$} & 407.771 & 0.0005 & 369965 & $0.0005-1000$ & 1 & & 291.139 & 0.03 & 2955 & $0.03-1000$ & 1 \\
\hline & 421.553 & 0.0009 & 270567 & $0.0009-1000$ & 1 & & 307.760 & 0.07 & 3321 & $0.07-950$ & 2 \\
\hline & 460.733 & 0.009 & 2054 & $0.009-990$ & 2 & $\mathrm{Mg}$ & 202.647 & 0.02 & 371 & $0.02-800$ & 2 \\
\hline \multirow[t]{4}{*}{$\operatorname{Pr}$} & 411.846 & 0.06 & 2705 & $0.06-1000$ & 1 & & 279.079 & 0.14 & 302 & $0.14-750$ & 3 \\
\hline & 414.311 & 0.06 & 3394 & $0.06-1000$ & 1 & & 279.553 & 0.0006 & 54115 & $0.0006-1000$ & 1 \\
\hline & 417.939 & 0.24 & 2958 & $0.24-900$ & 1 & & 280.270 & 0.001 & 41616 & $0.001-1000$ & 2 \\
\hline & 422.535 & 0.10 & 2628 & $0.10-900$ & 2 & & 285.213 & 0.008 & 10847 & $0.008-1000$ & 1 \\
\hline
\end{tabular}


Silver (Ag)

The detection limit trend for the four lines of $\mathrm{Ag}$ is: $328.068 \mathrm{~nm}$ $<338.289 \mathrm{~nm}<243.779 \mathrm{~nm}<$ $224.641 \mathrm{~nm}$, respectively. The sensitivity trend is just reverse of the detection limit trend. Although the contribution of Dy on the 328.068$\mathrm{nm}$ line is slightly higher than that of the 338.289-nm line, the 328.068-nm line was selected as the best analytical line for Ag by also keeping in mind the analytical performance result.

\section{Boron (B)}

The detection limit of all four lines of B (182.641 nm, 208.959 $\mathrm{nm}, 249.677 \mathrm{~nm}$, and $249.773 \mathrm{~nm}$ ) is almost similar, but the contribution of Dy on the 208.959-nm line is least, and the sensitivity of this line is higher than any other line of $\mathrm{B}$. Hence, this line was selected as the best analytical line for the determination of B in a Dy matrix.

\section{Chromium (Cr)}

The contribution of Dy on the five lines of $\mathrm{Cr}$ follows the trend: $205.618 \mathrm{~nm}<284.325 \mathrm{~nm}<$ $267.716 \mathrm{~nm}<283.563 \mathrm{~nm}<$ $284.984 \mathrm{~nm}$. Also, the detection limit of the 205.618-nm line is far better than the other lines of $\mathrm{Cr}$. Thus, the 205.618-nm line was chosen as the best analytical line for the determination of $\mathrm{Cr}$ in a Dy matrix.

\section{Effect of Dy Matrix on Ga, Ni, Gd, Ce, Nd, Al, In, $\mathrm{Pb}$ and $\mathrm{Ba}$}

These analytes are grouped on the basis of the minimum contribution of Dy on the line(s) of all of these analytes, which is greater than the minimum contribution on the line(s) of the previously described analytes as listed in Table VII. The analytical performance results of the following analytes are listed in Table VIII.

\section{Gallium (Ga)}

Of the three lines of $\mathrm{Ga}(417.206$ $\mathrm{nm}, 294.364 \mathrm{~nm}$, and $287.424 \mathrm{~nm}$ ), only the first one has a lower contribution of Dy with a higher tolerance level and best analytical performance. Hence, it was chosen as the best analytical line for $\mathrm{Ga}$ in a Dy matrix.

\section{Nickel (Ni)}

Some of the lines of $\mathrm{Ni}$ (227.021 $\mathrm{nm}, 231.604 \mathrm{~nm}, 232.003 \mathrm{~nm}$, and $341.476 \mathrm{~nm}$ ) have a closer value of detection limit, but only the 227.021-nm line interfered least. It is thus considered suitable for the determination of $\mathrm{Ni}$ in a Dy matrix.

\section{Gadolinium (Gd)}

The analytical performance results obtained for the four lines of Gd (335.047 nm, $335.862 \mathrm{~nm}$, $336.223 \mathrm{~nm}$, and $342.247 \mathrm{~nm}$ ), are very similar. However, on the basis of the spectral interference results, the $335.047-\mathrm{nm}$ line is considered best for the determination of $\mathrm{Gd}$ in a Dy matrix.

\section{Cesium (Ce)}

The detection limit for the five lines of Ce follows the trend: $413.765 \mathrm{~nm}<413.380 \mathrm{~nm}<$ $393.373 \mathrm{~nm}<418.660 \mathrm{~nm}<$ $448.691 \mathrm{~nm}$. The $413.765-\mathrm{nm}$ line shows a lower value of contribution from Dy compared to the other lines and hence, was selected for the determination of Ce in a Dy matrix.

\section{Neodymium (Nd)}

The contribution of Dy on all four lines of $\mathrm{Nd}(401.225 \mathrm{~nm}$, $406.109 \mathrm{~nm}, 417.731 \mathrm{~nm}$, and $430.358 \mathrm{~nm}$ ) is very much the same and the detection limit follows the trend: $430.358 \mathrm{~nm}<401.225 \mathrm{~nm}<$ $406.109 \mathrm{~nm}<417.731 \mathrm{~nm}$. The sensitivity follows the reverse trend. Thus, the 430.358-nm line was chosen for the determination of $\mathrm{Nd}$ in a Dy matrix.

\section{Aluminum (Al)}

Of the four analytical lines of $\mathrm{Al}$ (308.215 nm, $309.271 \mathrm{~nm}, 394.401$ $\mathrm{nm}, 396.152 \mathrm{~nm})$, the $309.271-\mathrm{nm}$ line was not interfered by Dy, but has a very high detection limit (3.03 $\mathrm{mg} / \mathrm{L}$ ). Based on the analytical performance and spectral interference study, the 394.401-nm line was selected for the determination of $\mathrm{Al}$ in a Dy matrix.

\section{Indium (In)}

The detection limit trend for the three lines of In follows the trend: $325.609 \mathrm{~nm}<230.606 \mathrm{~nm}<$ $303.609 \mathrm{~nm}$. It was found that the 325.609-nm line is much more interfered by Dy than the 230.606$\mathrm{nm}$ line. Thus, the 230.606-nm line is considered more suitable for the determination of In in a Dy matrix.

\section{Lead $(\mathrm{Pb})$}

Among the four lines of $\mathrm{Pb}$ (220.353 nm, 261.418 nm, 283.305 $\mathrm{nm}$, and $405.778 \mathrm{~nm}$ ), the 283.305 $\mathrm{nm}$ line seems to be the best line for the determination of $\mathrm{Pb}$ in a $\mathrm{Dy}$ matrix, both from the analytical performance and spectral interference point of view.

\section{Barium (Ba)}

The 455.404-nm line of $\mathrm{Ba}$ possesses the best analytical perfomance compared to the other two lines (233.527 $\mathrm{nm}$ and 230.424 $\mathrm{nm})$. The spectral interference results did not vary much. Hence, the 455.404-nm line was chosen for the quantitative determination of $\mathrm{Ba}$ in a Dy matrix.

\section{Validation of Method for the Direct Determination of Analytes in a Dy Matrix}

The aim of developing a method for the direct determination of analytes in the presence of a highpurity dysprosium matrix and selecting the best line(s) for each different analyte was validated using six sets of synthetic samples. They were prepared using commercially available standard reference materials of the individual elemental solutions. The samples were then fed to a hotter argon plasma, and the results obtained were analyzed without chemical separation. 
TABLE V

Spectral Interference of Dy on Ca, Fe, Co, Cu, Tl, Ag, B, and Cr

\begin{tabular}{|c|c|c|c|c|c|c|c|c|c|}
\hline $\begin{array}{c}\text { Ele- } \\
\text { ments }\end{array}$ & $\begin{array}{c}\text { Analytical } \\
\text { Lines } \\
(\mathrm{nm})\end{array}$ & $\begin{array}{l}\text { Contribution } \\
\text { From } 500 \\
\text { mg/L of Dy }\end{array}$ & $\begin{array}{c}\text { Correction } \\
\text { Factor }\end{array}$ & $\begin{array}{c}\text { Tolerance } \\
\text { Level } \\
(\mathrm{mg} / \mathrm{L})\end{array}$ & $\begin{array}{c}\text { Ele- } \\
\text { ments }\end{array}$ & $\begin{array}{c}\text { Analytical } \\
\text { Lines } \\
(n m)\end{array}$ & $\begin{array}{l}\text { Contribution } \\
\text { From } 500 \\
\text { mg/L of Dy }\end{array}$ & $\begin{array}{l}\text { Correction } \\
\text { Factor }\end{array}$ & $\begin{array}{c}\text { Tolerance } \\
\text { Level } \\
(\mathrm{mg} / \mathrm{L})\end{array}$ \\
\hline \multirow[t]{6}{*}{$\mathrm{Ca}$} & 396.847 & 3.06 & $6.1 \times 10^{-3}$ & 0.05 & \multirow[t]{5}{*}{$\mathrm{Cu}$} & 324.754 & 0.24 & $4.8 \times 10^{-4}$ & 100 \\
\hline & 393.366 & 0.45 & $9.0 \times 10^{-4}$ & 0.05 & & 327.396 & 0.30 & $5.8 \times 10^{-4}$ & 50 \\
\hline & 317.933 & 1.40 & $2.9 \times 10^{-3}$ & 0.05 & & 224.700 & 0.35 & $7.0 \times 10^{-4}$ & 10 \\
\hline & 315.887 & 2.90 & $5.7 \times 10^{-3}$ & 200 & & 219.226 & 6.40 & $1.3 \times 10^{-2}$ & 0.05 \\
\hline & 183.801 & 5.91 & $1.2 \times 10^{-2}$ & 10 & & 219.958 & 1.02 & $2.0 \times 10^{-3}$ & 5 \\
\hline & 422.673 & 0.30 & $6.0 \times 10^{-4}$ & 0.05 & \multirow[t]{2}{*}{$\mathrm{Tl}$} & 190.864 & 0.23 & $4.6 \times 10^{4}$ & 50 \\
\hline \multirow[t]{10}{*}{$\mathrm{Fe}$} & 259.941 & 0.43 & $8.7 \times 10^{-4}$ & 1 & & 276.787 & $\#$ & - & 0.05 \\
\hline & 238.204 & 17.0 & $3.4 \times 10^{2}$ & 0.05 & \multirow[t]{4}{*}{$\mathrm{Ag}$} & 338.289 & 0.36 & $7.2 \times 10^{-4}$ & 200 \\
\hline & 239.562 & 0.22 & $4.4 \times 10^{-4}$ & 10 & & 328.068 & 0.57 & $1.1 \times 10^{-3}$ & 50 \\
\hline & 244.451 & 4.0 & $8.0 \times 10^{-3}$ & 1 & & 224.641 & 8.0 & $1.6 \times 10^{-2}$ & 50 \\
\hline & 261.187 & 1.2 & $2.4 \times 10^{-3}$ & 5 & & 243.779 & 1.03 & $2.0 \times 10^{-3}$ & 10 \\
\hline & 262.567 & 7.8 & $1.6 \times 10^{-2}$ & 10 & \multirow[t]{4}{*}{ B } & 249.773 & 0.53 & $1.0 \times 10^{-3}$ & 10 \\
\hline & 262.829 & 2.5 & $5.0 \times 10^{-3}$ & 5 & & 249.677 & 0.45 & $9.0 \times 10^{-4}$ & 50 \\
\hline & 275.573 & $\#$ & - & 1 & & 182.641 & 0.19 & $3.8 \times 10^{-4}$ & 200 \\
\hline & 241.331 & 4.55 & $9.1 \times 10^{-3}$ & 10 & & 208.959 & 0.13 & $2.6 \times 10^{-4}$ & 200 \\
\hline & 373.486 & 3.30 & $6.5 \times 10^{-3}$ & 5 & \multirow[t]{5}{*}{$\mathrm{Cr}$} & 267.716 & 0.95 & $1.9 \times 10^{-3}$ & 10 \\
\hline \multirow[t]{4}{*}{$\mathrm{Co}$} & 228.616 & 0.78 & $1.6 \times 10^{-3}$ & 1 & & 205.618 & 0.18 & $3.6 \times 10^{-4}$ & 100 \\
\hline & 238.892 & 0.34 & $6.9 \times 10^{-4}$ & 50 & & 283.563 & 1.06 & $2.1 \times 10^{-3}$ & 10 \\
\hline & 230.786 & 0.93 & $1.8 \times 10^{-3}$ & 5 & & 284.325 & 0.65 & $1.3 \times 10^{-3}$ & 200 \\
\hline & 237.862 & 0.16 & $3.1 \times 10^{-4}$ & 200 & & 284.984 & 1.60 & $3.3 \times 10^{-3}$ & 10 \\
\hline
\end{tabular}

*No interference.

\#Significant spectral interference.

TABLE VI

Analytical Performance of Ca, Fe, Co, Cu, Tl, Ag, B, and Cr in Dy Matrix

\begin{tabular}{|c|c|c|c|c|c|c|c|c|c|c|c|}
\hline $\begin{array}{c}\text { Ele- } \\
\text { ments }\end{array}$ & $\begin{array}{l}\text { Analytical } \\
\text { Lines } \\
(\mathrm{nm})\end{array}$ & $\begin{array}{c}\text { D.L. } \\
(\mathrm{mg} / \mathrm{L})\end{array}$ & $\begin{array}{c}\text { Sensitivity } \\
\text { (counts/ } \\
\mathrm{mg} / \mathrm{L})\end{array}$ & $\begin{array}{c}\text { Linear } \\
\text { Dynamic } \\
\text { Range }(\mathrm{mg} / \mathrm{L})\end{array}$ & $\begin{array}{l}\text { RSD } \\
(\%)\end{array}$ & $\begin{array}{c}\text { Ele- } \\
\text { ments }\end{array}$ & $\begin{array}{l}\text { Analytical } \\
\text { Lines } \\
(\mathrm{nm})\end{array}$ & $\begin{array}{c}\text { D.L. } \\
(\mathrm{mg} / \mathrm{L})\end{array}$ & $\begin{array}{l}\text { Sensitivity } \\
\text { (counts/ } \\
\text { mg/L) }\end{array}$ & $\begin{array}{c}\text { Linear } \\
\text { Dynmaic } \\
\text { Range }(\mathrm{mg} / \mathrm{L})\end{array}$ & $\begin{array}{l}\text { RSD } \\
(\%)\end{array}$ \\
\hline \multirow[t]{6}{*}{$\mathrm{Ca}$} & 183.801 & 0.80 & 19 & $0.80-500$ & 3 & \multirow[t]{5}{*}{$\mathrm{Cu}$} & 219.226 & 0.02 & 290 & $0.02-1000$ & 1 \\
\hline & 315.887 & 0.15 & 972 & $0.15-800$ & 4 & & 219.958 & 0.05 & 548 & $0.05-1000$ & 1 \\
\hline & 317.933 & 0.04 & 2936 & $0.04-1000$ & 2 & & 224.700 & 0.02 & 1310 & $0.02-1000$ & 1 \\
\hline & 393.366 & 0.0009 & 586502 & $0.0009-1000$ & 1 & & 324.754 & 0.002 & 41210 & $0.002-1000$ & 1 \\
\hline & 396.847 & 0.002 & 442492 & $0.002-1000$ & 1 & & 327.396 & 0.005 & 27554 & $0.005-1000$ & 1 \\
\hline & 422.673 & 0.008 & 21893 & $0.008-1000$ & 1 & \multirow[t]{2}{*}{$\mathrm{Tl}$} & 190.864 & 0.06 & 674 & $0.06-1000$ & 3 \\
\hline \multirow[t]{10}{*}{$\mathrm{Fe}$} & 238.204 & 0.11 & 524 & $0.11-700$ & 4 & & 276.787 & 1.0 & 19 & $1.0-950$ & 5 \\
\hline & 239.562 & 0.02 & 1719 & $0.02-800$ & 4 & \multirow[t]{4}{*}{$\mathrm{Ag}$} & 224.641 & 1.99 & 34 & $1.99-700$ & 5 \\
\hline & 241.331 & 0.49 & 137 & $0.49-800$ & 3 & & 243.779 & 0.16 & 360 & $0.16-800$ & 4 \\
\hline & 244.451 & 0.26 & 115 & $0.26-900$ & 3 & & 328.068 & 0.01 & 11359 & $0.01-1000$ & 1 \\
\hline & 259.941 & 0.03 & 1224 & $0.03-1000$ & 2 & & 338.289 & 0.02 & 6258 & $0.02-1000$ & 1 \\
\hline & 261.187 & 0.05 & 651 & $0.05-1000$ & 1 & \multirow[t]{4}{*}{ B } & 182.641 & 0.03 & 554 & $0.05-1000$ & 2 \\
\hline & 262.567 & 0.68 & 93 & $0.68-1000$ & 1 & & 208.959 & 0.02 & 3080 & $0.02-1000$ & 2 \\
\hline & 262.829 & 0.42 & 123 & $0.42-750$ & 2 & & 249.677 & 0.05 & 787 & $0.05-1000$ & 2 \\
\hline & 275.573 & 0.21 & 222 & $0.21-900$ & 1 & & 249.773 & 0.02 & 1240 & $0.02-1000$ & 2 \\
\hline & 373.486 & 0.09 & 2086 & $0.09-1000$ & 2 & \multirow[t]{5}{*}{$\mathrm{Cr}$} & 205.618 & 0.004 & 5765 & $0.004-1000$ & 1 \\
\hline \multirow[t]{4}{*}{ Co } & 228.616 & 0.05 & 588 & $0.05-950$ & 1 & & 267.716 & 0.11 & 545 & $0.11-800$ & 2 \\
\hline & 230.786 & 0.08 & 506 & $0.08-950$ & 1 & & 283.563 & 0.01 & 3220 & $0.01-1000$ & 3 \\
\hline & 237.862 & 0.02 & 1006 & $0.02-1000$ & 1 & & 284.325 & 0.35 & 1302 & $0.35-900$ & 3 \\
\hline & 238.892 & 0.05 & 1459 & $0.05-1000$ & 1 & & 284.984 & 0.22 & 385 & $0.22-900$ & 3 \\
\hline
\end{tabular}




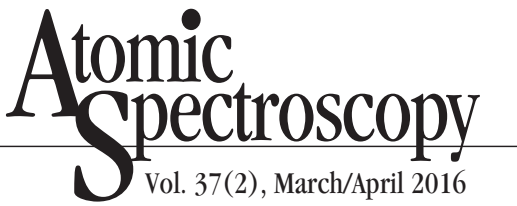

TABLE VII

Spectral Interference of $\mathrm{Dy}$ on $\mathrm{Ga}, \mathrm{Ni}, \mathrm{Gd}, \mathrm{Ce}, \mathrm{Nd}, \mathrm{Al}, \mathrm{In}, \mathrm{Pb}$, and $\mathrm{Ba}$

\begin{tabular}{|c|c|c|c|c|c|c|c|c|c|}
\hline $\begin{array}{l}\text { Ele- } \\
\text { ments }\end{array}$ & $\begin{array}{l}\text { Analytical } \\
\text { Lines } \\
(\mathrm{nm})\end{array}$ & $\begin{array}{l}\text { Contribution } \\
\text { From } 500 \\
\mathrm{mg} / \mathrm{L} \text { of Dy }\end{array}$ & $\begin{array}{l}\text { Correction } \\
\text { Factor }\end{array}$ & $\begin{array}{l}\text { Tolerance } \\
\text { Level } \\
(\mathrm{mg} / \mathrm{L})\end{array}$ & $\begin{array}{c}\text { Ele- } \\
\text { ments }\end{array}$ & $\begin{array}{l}\text { Analytical } \\
\text { Lines } \\
(\mathrm{nm})\end{array}$ & $\begin{array}{l}\text { Contribution } \\
\text { From } 500 \\
\mathrm{mg} / \mathrm{L} \text { of } \mathrm{Dy}\end{array}$ & $\begin{array}{l}\text { Correction } \\
\text { Factor }\end{array}$ & $\begin{array}{l}\text { Tolerance } \\
\text { Level } \\
\text { (mg/L) }\end{array}$ \\
\hline \multirow[t]{3}{*}{$\mathrm{Ga}$} & 417.206 & 0.71 & $1.4 \times 10^{-3}$ & 50 & \multirow[t]{4}{*}{$\mathrm{Nd}$} & 401.225 & 1.30 & $2.6 \times 10^{-3}$ & 5 \\
\hline & 294.364 & 7.3 & $1.5 \times 10^{-2}$ & 1 & & 430.358 & 1.02 & $2.0 \times 10^{-3}$ & 5 \\
\hline & 287.424 & 12.0 & $2.4 \times 10^{2}$ & 5 & & 406.109 & 1.12 & $2.2 \times 10^{-3}$ & 5 \\
\hline \multirow[t]{6}{*}{$\mathrm{Ni}$} & 231.604 & 1.06 & $2.1 \times 10^{-3}$ & 100 & & 417.731 & 0.97 & $2.0 \times 10^{-3}$ & 5 \\
\hline & 221.648 & 0.86 & $1.7 \times 10^{-3}$ & 100 & \multirow[t]{4}{*}{$\mathrm{Al}$} & 396.152 & 6.80 & $1.4 \times 10^{-2}$ & 1 \\
\hline & 232.003 & 14.6 & $3.0 \times 10^{-2}$ & 0.05 & & 394.401 & 3.02 & $1.0 \times 10^{-2}$ & 10 \\
\hline & 227.021 & 0.71 & $1.4 \times 10^{-3}$ & 100 & & 308.215 & 4.02 & $8.0 \times 10^{-3}$ & 1 \\
\hline & 300.249 & 6.4 & $1.2 \times 10^{2}$ & 10 & & 309.271 & $*$ & - & 500 \\
\hline & 341.476 & \# & - & 0.05 & \multirow[t]{3}{*}{ In } & 230.606 & 3.0 & $5.8 \times 10^{-3}$ & 10 \\
\hline \multirow[t]{4}{*}{ Gd } & 342.247 & 4.7 & $9.3 \times 10^{-3}$ & 10 & & 325.609 & 8.50 & $1.7 \times 10^{-2}$ & 1 \\
\hline & 335.047 & 0.70 & $1.4 \times 10^{-3}$ & 2 & & 303.936 & 11.7 & $2.3 \times 10^{-2}$ & 10 \\
\hline & 336.223 & 2.0 & $4.0 \times 10^{-3}$ & 2 & \multirow[t]{4}{*}{$\mathrm{Pb}$} & 220.353 & 2.72 & $5.4 \times 10^{-3}$ & 1 \\
\hline & 335.862 & 10.9 & $2.2 \times 10^{-2}$ & 10 & & 405.778 & 4.70 & $9.3 \times 10^{-3}$ & 100 \\
\hline \multirow[t]{5}{*}{$\mathrm{Ce}$} & 418.660 & 5.60 & $1.1 \times 10^{-2}$ & 5 & & 283.305 & 2.34 & $4.7 \times 10^{-3}$ & 5 \\
\hline & 448.691 & \# & - & 500 & & 261.418 & 16.7 & $3.3 \times 10^{-2}$ & 10 \\
\hline & 413.765 & 1.32 & $2.6 \times 10^{-3}$ & 5 & \multirow[t]{3}{*}{$\mathrm{Ba}$} & 455.404 & 1.06 & $2.1 \times 10^{-3}$ & 10 \\
\hline & 413.380 & 3.30 & $6.6 \times 10^{-3}$ & 5 & & 233.527 & 2.43 & $4.8 \times 10^{-3}$ & 10 \\
\hline & 393.373 & $\#$ & - & 500 & & 230.424 & 0.90 & $1.8 \times 10^{-3}$ & 50 \\
\hline
\end{tabular}

*No interference. \#Significant spectral interference.

TABLE VIII

Analytical Performance of Dy on Ga, Ni, Gd, Ce, Nd, Al, In, Pb, and Ba

\begin{tabular}{|c|c|c|c|c|c|c|c|c|c|c|c|}
\hline $\begin{array}{l}\text { Ele- } \\
\text { ments }\end{array}$ & $\begin{array}{l}\text { Analytical } \\
\text { Lines } \\
(\mathrm{nm})\end{array}$ & $\begin{array}{c}\text { D.L. } \\
(\mathrm{mg} / \mathrm{L})\end{array}$ & $\begin{array}{l}\text { Sensitivity } \\
\text { (counts/ } \\
\text { mg/L) }\end{array}$ & $\begin{array}{c}\text { Linear } \\
\text { Dynamic } \\
\text { Range }(\mathrm{mg} / \mathrm{L})\end{array}$ & $\begin{array}{l}\text { RSD } \\
(\%)\end{array}$ & $\begin{array}{l}\text { Ele- } \\
\text { ments }\end{array}$ & $\begin{array}{l}\text { Analytical } \\
\text { Lines } \\
(\mathrm{nm})\end{array}$ & $\begin{array}{c}\text { D.L. } \\
(\mathrm{mg} / \mathrm{L})\end{array}$ & $\begin{array}{c}\text { Sensitivity } \\
\text { (counts/ } \\
\text { mg/L) }\end{array}$ & $\begin{array}{l}\text { Linear } \\
\text { Dynamic } \\
\text { Range }(\mathrm{mg} / \mathrm{L})\end{array}$ & $\begin{array}{l}\text { RSD } \\
(\%) \\
\end{array}$ \\
\hline \multirow[t]{3}{*}{$\mathrm{Ga}$} & 287.424 & 0.43 & 155 & $0.43-750$ & 3 & \multirow[t]{4}{*}{$\mathrm{Nd}$} & 401.225 & 0.06 & 3206 & $0.06-1000$ & 1 \\
\hline & 294.364 & 0.12 & 642 & $0.12-950$ & 3 & & 406.109 & 0.12 & 2168 & $0.12-950$ & 3 \\
\hline & 417.206 & 0.10 & 7204 & $0.10-950$ & 3 & & 417.731 & 0.24 & 1795 & $0.24-950$ & 3 \\
\hline \multirow[t]{6}{*}{$\mathrm{Ni}$} & 221.648 & 0.18 & 679 & $0.18-900$ & 2 & & 430.358 & 0.04 & 3467 & $0.04-1000$ & 1 \\
\hline & 227.021 & 0.08 & 102 & $0.08-1000$ & 2 & \multirow[t]{4}{*}{$\mathrm{Al}$} & 308.215 & 0.04 & 1338 & $0.04-1000$ & 2 \\
\hline & 231.604 & 0.02 & 651 & $0.02-1000$ & 1 & & 309.271 & 3.03 & 2539 & $3.03-700$ & 2 \\
\hline & 232.003 & 0.04 & 548 & 0.04-1000 & 1 & & 394.401 & 0.06 & 3141 & $0.06-1000$ & 2 \\
\hline & 300.249 & 0.36 & 440 & $0.36-700$ & 3 & & 396.152 & 0.02 & 9690 & $0.02-1000$ & 2 \\
\hline & 341.476 & 0.01 & 4082 & $0.01-1000$ & 1 & \multirow[t]{3}{*}{ In } & 230.606 & 0.18 & 517 & $0.18-950$ & 2 \\
\hline \multirow[t]{4}{*}{$\mathrm{Gd}$} & 335.047 & 0.03 & 4845 & $0.03-1000$ & 2 & & 303.936 & 0.32 & 375 & $0.32-950$ & 2 \\
\hline & 335.862 & 0.06 & 2913 & $0.06-1000$ & 2 & & 325.609 & 0.06 & 1115 & $0.06-950$ & 2 \\
\hline & 336.223 & 0.06 & 3462 & $0.06-1000$ & 2 & \multirow[t]{4}{*}{$\mathrm{Pb}$} & 220.353 & 0.17 & 219 & $0.17-900$ & 2 \\
\hline & 342.247 & 0.03 & 4753 & $0.03-1000$ & 2 & & 261.418 & 0.90 & 53 & $0.90-900$ & 3 \\
\hline \multirow[t]{5}{*}{$\mathrm{Ce}$} & 393.373 & 0.26 & 2821 & $0.26-900$ & 3 & & 283.305 & 0.08 & 547 & $0.08-1000$ & 1 \\
\hline & 413.380 & 0.07 & 2414 & $0.07-1000$ & 1 & & 405.778 & 0.27 & 707 & $0.27-1000$ & 1 \\
\hline & 413.765 & 0.06 & 2406 & $0.06-1000$ & 1 & \multirow[t]{3}{*}{$\mathrm{Ba}$} & 230.424 & 0.14 & 745 & $0.14-900$ & 3 \\
\hline & 418.660 & 0.33 & 1968 & $0.33-900$ & 3 & & 233.527 & 0.23 & 364 & $0.23-900$ & 3 \\
\hline & 448.691 & 2.0 & 60 & $2.0-900$ & 5 & & 455.404 & 0.03 & 2900 & 0.03-1000 & 1 \\
\hline
\end{tabular}


The elemental concentrations of six synthetic samples prepared for the present study were as follows:

1. Synthetic sample 1 (S 1): $0.1 \mathrm{mg} / \mathrm{L}$ of Cd, Li, Mn, Sr, Pr, Na, $\mathrm{Zn}, \mathrm{La}, \mathrm{Lu}$, and $\mathrm{Mg}$ in $500 \mathrm{mg} / \mathrm{L}$ of Dy.

2. Synthetic sample 2 (S 2): $1 \mathrm{mg} / \mathrm{L}$ of $\mathrm{Cd}, \mathrm{Li}, \mathrm{Mn}, \mathrm{Sr}, \mathrm{Pr}, \mathrm{Na}, \mathrm{Zn}$, $\mathrm{La}, \mathrm{Lu}$, and $\mathrm{Mg}$ in $500 \mathrm{mg} / \mathrm{L}$ of Dy.

3. Synthetic sample 3 (S 3): $0.2 \mathrm{mg} / \mathrm{L}$ of $\mathrm{Ca}, \mathrm{Fe}, \mathrm{Co}, \mathrm{Cu}, \mathrm{Tl}, \mathrm{Ag}$, $\mathrm{B}$, and $\mathrm{Cr}$ in $500 \mathrm{mg} / \mathrm{L}$ of Dy.

4. Synthetic sample 4 (S 4): $2 \mathrm{mg} / \mathrm{L}$ of $\mathrm{Ca}, \mathrm{Fe}, \mathrm{Co}, \mathrm{Cu}, \mathrm{Tl}, \mathrm{Ag}, \mathrm{B}$, and $\mathrm{Cr}$ in $500 \mathrm{mg} / \mathrm{L}$ of Dy.

5. Synthetic sample 5 (S 5): $1 \mathrm{mg} / \mathrm{L}$ of $\mathrm{Ga}, \mathrm{Ni}, \mathrm{Gd}, \mathrm{Ce}, \mathrm{Nd}, \mathrm{Al}$, $\mathrm{In}, \mathrm{Pb}$, and $\mathrm{Ba}$ in $500 \mathrm{mg} / \mathrm{L}$ of $\mathrm{Dy}$.

6. Synthetic sample 6 (S 6): $5 \mathrm{mg} / \mathrm{L}$ of $\mathrm{Ga}, \mathrm{Ni}, \mathrm{Gd}, \mathrm{Ce}, \mathrm{Nd}, \mathrm{Al}$, $\mathrm{In}, \mathrm{Pb}$, and $\mathrm{Ba}$ in $500 \mathrm{mg} / \mathrm{L}$ of $\mathrm{Dy}$.

From the results obtained, it is evident that $\mathrm{Cd}, \mathrm{Li}, \mathrm{Mn}, \mathrm{Sr}, \mathrm{Pr}, \mathrm{Na}$, $\mathrm{Zn}$, La, Lu, and $\mathrm{Mg}$ can be estimated even at $0.1 \mathrm{mg} / \mathrm{L}$ in the presence of a dysprosium matrix. The analytes $\mathrm{Ca}, \mathrm{Fe}, \mathrm{Co}, \mathrm{Cu}, \mathrm{Tl}, \mathrm{Ag}, \mathrm{B}$, and $\mathrm{Cr}$ were slightly interfered by Dy and can be estimated at $0.2 \mathrm{mg} / \mathrm{L}$. The analytes $\mathrm{Ga}, \mathrm{Ni}, \mathrm{Gd}, \mathrm{Ce}, \mathrm{Nd}, \mathrm{Al}$, In,
$\mathrm{Pb}$, and $\mathrm{Ba}$, which were significantly interfered by Dy, can be estimated as low as $1 \mathrm{mg} / \mathrm{L}$ in the presence of $500 \mathrm{mg} / \mathrm{L}$ of Dy. The analyses results of the synthetic samples are listed in Tables IX-XI.

\section{CONCLUSION}

The systematic studies on the spectral interference of Dy on different analytes and the analytical performance of the different analytical lines of these analytes revealed that the Cd $226.502 \mathrm{~nm}, \mathrm{Li} 670.780$ $\mathrm{nm}, \mathrm{Sr} 421.552 \mathrm{~nm}, \mathrm{Mg} 279.553 \mathrm{~nm}$, Mn $259.373 \mathrm{~nm}$, Na $588.995 \mathrm{~nm}$

TABLE IX

Validation of Method Using Synthetic Samples Containing Cd, Li, Sr, Mg, Mn, Na, Zn, La, Lu, and Pr in Dy Matrix

\begin{tabular}{cc|cc|cc}
\hline & & \multicolumn{2}{|c|}{$\mathrm{S} 1$} & \multicolumn{2}{c}{$\mathrm{S} 2$} \\
\hline $\begin{array}{c}\text { Ele- } \\
\text { ments }\end{array}$ & $\begin{array}{c}\text { Analytical } \\
\text { Lines } \\
(\mathrm{nm})\end{array}$ & $\begin{array}{c}\text { Actual } \\
\text { Conc. } \\
(\mathrm{mg} / \mathrm{L})\end{array}$ & $\begin{array}{c}\text { Amount } \\
\text { After Incorporating } \\
\text { Correction Factor } \\
(\mathrm{mg} / \mathrm{L})\end{array}$ & $\begin{array}{c}\text { Actual } \\
\text { Conc. } \\
(\mathrm{mg} / \mathrm{L})\end{array}$ & $\begin{array}{c}\text { Amount } \\
\text { After Incorporating } \\
\text { Correction Factor } \\
(\mathrm{mg} / \mathrm{L})\end{array}$ \\
\hline $\mathrm{Cd}$ & 226.502 & 0.1 & $0.098 \pm 0.004$ & 1 & $1.2 \pm 0.4$ \\
$\mathrm{Li}$ & 670.78 & 0.1 & $0.106 \pm 0.005$ & 1 & $0.98 \pm 0.2$ \\
$\mathrm{Sr}$ & 421.552 & 0.1 & $0.107 \pm 0.003$ & 1 & $1.1 \pm 0.4$ \\
$\mathrm{Mg}$ & 279.553 & 0.1 & $0.099 \pm 0.002$ & 1 & $1.0 \pm 0.4$ \\
$\mathrm{Mn}$ & 259.373 & 0.1 & $0.098 \pm 0.005$ & 1 & $0.99 \pm 0.4$ \\
$\mathrm{Na}$ & 588.995 & 0.1 & $0.100 \pm 0.004$ & 1 & $0.97 \pm 0.4$ \\
$\mathrm{Zn}$ & 213.856 & 0.1 & $0.111 \pm 0.004$ & 1 & $0.95 \pm 0.5$ \\
$\mathrm{La}$ & 408.672 & 0.1 & $0.097 \pm 0.005$ & 1 & $1.11 \pm 0.3$ \\
& 379.478 & 0.1 & $0.098 \pm 0.005$ & 1 & $1.23 \pm 0.4$ \\
$\mathrm{Lu}$ & 261.542 & 0.1 & $0.095 \pm 0.003$ & 1 & $1.0 \pm 0.5$ \\
$\mathrm{Pr}$ & 417.939 & 0.1 & $0.099 \pm 0.004$ & 1 & $1.0 \pm 0.5$ \\
\hline
\end{tabular}

TABLE X

Validation of Method Using Synthetic Samples Containing $\mathrm{Ca}, \mathrm{Fe}, \mathrm{Co}, \mathrm{Cu}, \mathrm{Tl}, \mathrm{Ag}, \mathrm{B}$, and $\mathrm{Cr}$ in Dy Matrix

\begin{tabular}{|c|c|c|c|c|c|c|c|}
\hline \multirow[b]{2}{*}{$\begin{array}{l}\text { Ele- } \\
\text { ments }\end{array}$} & \multirow[b]{2}{*}{$\begin{array}{l}\text { Analytical } \\
\text { Lines } \\
(\mathrm{nm})\end{array}$} & \multicolumn{3}{|c|}{ S3 } & \multicolumn{3}{|c|}{$\mathrm{S} 4$} \\
\hline & & $\begin{array}{l}\text { Actual } \\
\text { Conc. } \\
(\mathrm{mg} / \mathrm{L})\end{array}$ & \multicolumn{2}{|c|}{$\begin{array}{l}\text { Amount } \\
\text { Before After } \\
\text { Incorporating } \\
\text { Correction Factor } \\
(\mathrm{mg} / \mathrm{L}) \quad(\mathrm{mg} / \mathrm{L})\end{array}$} & $\begin{array}{l}\text { Actual } \\
\text { Conc. } \\
(\mathrm{mg} / \mathrm{L})\end{array}$ & $\begin{array}{l}\text { Am } \\
\text { Before } \\
\text { Incorp } \\
\text { Correcti } \\
(\mathrm{mg} / \mathrm{L})\end{array}$ & $\begin{array}{l}\text { After } \\
\text { ing } \\
\text { actor } \\
(\mathrm{mg} / \mathrm{L})\end{array}$ \\
\hline Ag & 328.068 & 0.2 & $0.75 \pm 0.03$ & 0.18 & 2 & $2.63 \pm 0.13$ & 2.06 \\
\hline B & 208.959 & 0.2 & $0.37 \pm 0.02$ & 0.24 & 2 & $1.94 \pm 0.11$ & 1.81 \\
\hline $\mathrm{Ca}$ & 393.366 & 0.2 & $0.64 \pm 0.03$ & 0.19 & 2 & $2.43 \pm 0.08$ & 1.98 \\
\hline Co & 237.862 & 0.2 & $0.39 \pm 0.04$ & 0.23 & 2 & $1.96 \pm 0.07$ & 1.79 \\
\hline $\mathrm{Cr}$ & 205.618 & 0.2 & $0.37 \pm 0.02$ & 0.19 & 2 & $2.20 \pm 0.08$ & 2.02 \\
\hline $\mathrm{Cu}$ & 324.754 & 0.2 & $0.42 \pm 0.02$ & 0.18 & 2 & $2.30 \pm 0.10$ & 2.07 \\
\hline $\mathrm{Fe}$ & 239.562 & 0.2 & $0.42 \pm 0.03$ & 0.2 & 2 & $2.17 \pm 0.13$ & 1.95 \\
\hline $\mathrm{Tl}$ & 190.864 & 0.2 & $0.43 \pm 0.03$ & 0.2 & 2 & $2.19 \pm 0.12$ & 1.96 \\
\hline
\end{tabular}




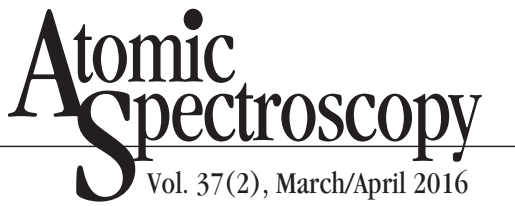

TABLE XI

Validation of Method Using Synthetic Sample Containing Ga, Ni, Ba, Gd, Nd, and Ce in Dy Matrix

\begin{tabular}{|c|c|c|c|c|c|c|c|}
\hline & & & S5 & & & 56 & \\
\hline $\begin{array}{c}\text { Ele- } \\
\text { ments }\end{array}$ & $\begin{array}{l}\text { Analytical } \\
\text { Lines } \\
\text { (nm) }\end{array}$ & $\begin{array}{l}\text { Actual } \\
\text { Conc. } \\
\text { (mg/L) }\end{array}$ & $\begin{array}{l}\text { Amol } \\
\text { Before } \\
\text { Incorpo } \\
\text { Correction }\end{array}$ & $\begin{array}{l}\text { t } \\
\text { After } \\
\text { ting } \\
\text { actor }\end{array}$ & $\begin{array}{l}\text { Actual } \\
\text { Conc. } \\
(\mathrm{mg} / \mathrm{L})\end{array}$ & $\begin{array}{l}\text { Amo } \\
\text { Before } \\
\text { Incorpo } \\
\text { Correctio }\end{array}$ & $\begin{array}{l}\text { After } \\
\text { ing } \\
\text { actor }\end{array}$ \\
\hline $\mathrm{Ga}$ & 417.206 & 1 & $1.80 \pm 0.07$ & 1.09 & 5 & $5.69 \pm 0.19$ & 4.98 \\
\hline $\mathrm{Ni}$ & 227.021 & 1 & $1.75 \pm 0.09$ & 1.04 & 5 & $5.76 \pm 0.23$ & 5.05 \\
\hline $\mathrm{Ba}$ & 455.404 & 1 & $2.10 \pm 0.11$ & 1.04 & 5 & $7.00 \pm 0.31$ & 5.94 \\
\hline Gd & 355.047 & 1 & $1.63 \pm 0.08$ & 0.93 & 5 & $5.6 \pm 0.22$ & 4.9 \\
\hline $\mathrm{Nd}$ & 430.358 & 1 & $1.96 \pm 0.10$ & 0.94 & 5 & $6.2 \pm 0.24$ & 5.18 \\
\hline $\mathrm{Ce}$ & 413.765 & 1 & $2.29 \pm 0.09$ & 0.97 & 5 & $6.4 \pm 0.26$ & 5.08 \\
\hline In & 230.606 & 1 & $4.11 \pm 0.15$ & 1.11 & 5 & $8.1 \pm 0.39$ & 5.1 \\
\hline $\mathrm{Pb}$ & 283.305 & 1 & $3.40 \pm 0.13$ & 1.06 & 5 & $7.5 \pm 0.32$ & 5.16 \\
\hline $\mathrm{Al}$ & 394.401 & 1 & $3.96 \pm 0.17$ & 0.94 & 5 & $7.9 \pm 0.33$ & 4.88 \\
\hline
\end{tabular}

and $589.592 \mathrm{~nm}, \mathrm{Zn} 213.856 \mathrm{~nm}$, La $408.672 \mathrm{~nm}$ and $379.478 \mathrm{~nm}$, Lu $261.542 \mathrm{~nm}$, and $\operatorname{Pr} 417.939 \mathrm{~nm}$ analytical lines were not interfered by Dy. These lines also showed the best analytical performance and hence, can be chosen for the determination of these analytes in the presence of a Dy matrix without chemical separation and without incorporation of the correction factors. The Ag $328.068 \mathrm{~nm}$, B $208.959 \mathrm{~nm}$, Ca $393.366 \mathrm{~nm}$, Co $237.862 \mathrm{~nm}$, Cr $205.618 \mathrm{~nm}$, Cu324.754 nm, Fe $239.562 \mathrm{~nm}$, Tl $190.864 \mathrm{~nm}$, Ga $417.206 \mathrm{~nm}$, Ni $227.021 \mathrm{~nm}$, Ba $455.404 \mathrm{~nm}$, Gd $355.047 \mathrm{~nm}, \mathrm{Nd} 430.358 \mathrm{~nm}$, Ce $413.765 \mathrm{~nm}, \mathrm{Al} 394.401 \mathrm{~nm}$, $\mathrm{Pb} 283.305 \mathrm{~nm}$, and In $230.606 \mathrm{~nm}$ analytical lines were found to be the best analytical lines of these elements. A simple, rapid ICP-AESbased method was developed for the determination these 27 analytes in a Dy matrix without chemical separation. The method was validated using synthetic samples prepared from commercially available standard reference materials of the individual solutions. The present approach appeared to be exciting and the analytical data were found to be in good agreement.
Received March 16, 2015.

\section{REFERENCES}

1. N. Zhang, B. Hu and C. Huang, , Anal. Chim. Acta 597, 12 (2007).

2. C. Chen, P. Zhang and Z. Chai, Anal. Chim. Acta 439, 19 (2001).

3. S. Gu, H. Ying, Z. Zhang, Z.Zhuang, P. Yang, X. Wang, B. Huang and B. Li, Spectrochim. Acta, Part B, 52, 1567 (1997).

4. S.S. Biswas, A. Sethumadhavan and P.S. Murty, Determination of Y, $\mathrm{Sm}, \mathrm{Eu}, \mathrm{Gd}, \mathrm{Dy}, \mathrm{Ho}, \mathrm{Er}$, in High Purity Terbium Oxide by ICP-AES, 1, 71 (1991).

5. Information from http://www.nanoamor.com, Nanostructured and Amorphous Material Inc., Houston, TX, USA.

6. Z.D. Zhang, J. Mater. Sci. Technol, 23, 1 (2007).

7. J. Schoenes, J. Alloys Compd, Magneto-optic lanthanide materials, 250, 627 (1997).

8. S. Ma, W.B. Cui, D. Li, N.K. Sun, D. Y. Geng, X. Jiang, and Z. D. Zhang, Appl. Phys. Lett. 92 (2008) (17), (173113-1)-(173113-3).

9. X.G. Liu, S.W. Or, B. Li, Z.Q. Ou, L. Zhang, Q. Zhang, D.Y. Geng, F. Yang, D. Li, E. Bruck and Z.D.
Zhang, J. Nanopart. Res. 13, 1163 (2011).

10. M. Chandrasekhar, D.V. Sunitha, N. Dhananjaya, H. Nagabhushana, S.C. Sharma, B.M. Nagabhushana, C. Shivakumara and R.P.S. Chakradhar, Materials Research Bull. 47, 2085 (2012).

11. D. A. Sadler and D. L.John, J. of Anal. At. Spectrom. 11, 1105 (1996).

12. J.A.C. Broekaert, F. Leis and $\mathrm{K}$. Laqua, Spectrochim. Acta, Part B, 34, 73 (1979).

13. I. B. Brenner, A. E. Watson, T. W. Steele, E. A. Jones and M. Goncalves, Spectrochim. Acta, Part B, 36, 785 (1981).

14. T. K. Seshagiri, Y. Babu, M. L. Jayanthkumar, A.G.I.Dalvi, M. D. Sastry and B. D. Joshi, Talanta 31, 773 (1984)

15. E.L.Yen-Bower and J. D. Winefordner, Anal. Chim. Acta 101, 319 (1978).

16. R. P. Bateh and J. D. Winefordner, Anal. Lett. 15, 373(1982).

17. R. P. Bateh and J. D.Winefordner, J. Pharm. Biomed. Anal. 1, 113 (1983).

18. D. W. Zachmann, Anal. Chem. 60, 420.(1988).

19. T. Vo-Dinh, Room Temperature Phosphorimetty for Chemical 
Analysis, P. J. Eking and J. D. Winefordner, Eds.; Wiley \& Sons,, New York, USA (1984).

20. M. M. Andino, M. A. Kosinski and J. D. Winefordner, Anal. Chem. 58, 1730 (1986)

21. C. G. de Lima, M. M. Andino and J. D. Winefordner, Anal. Chem. 58 2867(1986).

22. H. Qing-Lie, T. C. Hughes, M. Haukka and P. Hannaker, Talanta 32, 495.(1985).

23. A. Sengupta, S.K. Thulasidas and V. Natarajan, At. Spectrosc. 35(6), 247 (2014)

24. Y. Airan, A. Sengupta, S.K. Thulasidas and V. Natarajan, At. Spectrosc. 36(1), 30 (2015).

25. A. Sengupta, Y. Airan, S.K. Thulasidas and V. Natarajan, At. Spectrosc. 36(2), 82 (2015) 95.

26. Y. Airan, A. Sengupta, S.K. Thulasidas, and V. Natarajan, At. Spectrosc. 36(1), 15 (2015).

27. A. Sengupta, S.K. Thulasidas, and V. Natarajan, At. Spectrosc. 35(5), 213 (2014).

28. A. Sengupta and V.C. Adya, J. Radioanal. Nucl. Chem. 299, 2023 (2014).

29. A. Sengupta and V.C. Adya, At. Spectrosc. 34(6), 207 (2013).

30. V.C. Adya, A. Sengupta and S.V. Godbole, At. Spectrosc. 35(1), 25 (2014). 